\title{
PENGARUH BUDAYA ORGANISASI, KEPUASAN KERJA DAN GAYA KEPEMIMPINAN KEPALA SEKOLAH TERHADAP KOMITMEN KERJA GURU MAN 1 DAN MAN 2 PEKANBARU
}

\author{
Herlina ${ }^{1)}$ \\ Zulkarnaini ${ }^{2)}$ \\ Murni Baheram ${ }^{3)}$ \\ 1) Post Graduate Student of Riau University \\ 2) Lecturer of Education Management Study Programme PPS University of Riau \\ ${ }^{3)}$ Lecturer of Education Management Study Programme PPs University of Riau
}

\begin{abstract}
This study aims to determine the influence of variables (1) the principal's leadership style on organizational culture, (2) the principal's leadership style on job satisfaction, (3) organizational culture on teacher work commitments, (4) job satisfaction on teacher work commitments, (5) the principal's leadership style on teacher work commitments. Research respondents were MAN 1 and MAN 2 Pekanbaru teachers, totaling 165 people with a sample of 117. Data analysis used was path analysis. The results showed that there was a direct influence on the principal's leadership style on organizational culture, there was a direct influence on the principal's leadership style on job satisfaction, there was a direct influence on organizational culture on teacher work commitments, and there was a direct effect on job satisfaction on teacher work commitments, there was a direct influence on style the principal's leadership towards the teacher's work commitment.
\end{abstract}

Keywords: Organizational Culture, Job Satisfaction, Principal's leadership style and teacher's work commitment.

\begin{abstract}
ABSTRAK
Penelitian ini bertujuan untuk mengetahui adanya pengaruh variabel (1) gaya kepemimpinan kepala sekolah terhadap budaya organisasi, (2) gaya kepemimpinan kepala sekolah terhadap kepuasan kerja,(3) budaya organisasi terhadap komitmen kerja guru, (4) kepuasan kerja terhadap komitmen kerja guru,(5) gaya kepemimpinan kepala sekolah terhadap komitmen kerja guru. Responden penelitian adalah guru MAN 1 dan MAN 2 Pekanbaru yang berjumlah 165 orang dengan sampel 117. Analisis data yang digunakan yaitu analisis jalur (path analisis). Hasil penelitian menunjukkan adanya pengaruh langsung gaya kepemimpinan kepala sekolah terhadap budaya organisasi, terdapat pengaruh langsung gaya kepemimpinan kepala sekolah terhadap kepuasan kerja, terdapat pengaruh langsung budaya organisasi terhadap komitmen kerja guru, dan terdapat pengaruh langsung kepuasan kerja terhadap komitmen kerja guru, terdapat pengaruh langsung gaya kepemimpinan kepala sekolah terhadap komitmen kerja guru.
\end{abstract}

Kata Kunci: Budaya Organisasi, Kepuasan Kerja, Gaya kepemimpinan Kepala Sekolah dan Komitmen Kerja guru. 


\section{PENDAHULUAN}

Dunia pendidikan mempunyai peran yang penting bagi pengembangan sumber daya manusia untuk menciptakan masyarakat yang berkualitas. Berbagai upaya untuk meningkatkan kualitas pendidikan telah dilakukan oleh pemerintah maupun pihak swasta. Untuk mencapai masyarakat yang berkualitas dibutuhkan keselarasan berbagai pihak dalam mengembangkan sumber daya manusia. Penyelenggaraan pendidikan berkualitas merupakan prasyarat bagi terciptanya peningkatan sumber daya manusia.

Guru merupakan faktor kunci keberhasilan pendidikan, karena dengan adanya keberadaan guru sangat berpengaruh terhadap semua sumber daya pendidikan yang ada seperti, sarana dan prasarana, biaya, teknologi, dan informasi dapat berfungsi dengan baik apabila guru memiliki komitmen yang kuat dalam pelaksanaan tugas dan tanggung jawabnya, untuk terus memperbaiki kualitas pendidikan dan menghasilkan generasi penerus bangsa yang mampu bersaing pada tingkat nasional maupun tingkat internasional.

Guru merupakan orang yang sangat berpengaruh dalam proses belajar mengajar. Sebagai pelaksana pendidikan guru memegang peranan penting dalam penentuan tercapainya tujuan pembelajaran. Guru tidak hanya bertanggung jawab menyampaikan pelajaran, tetapi juga harus dapat menciptakan suasana belajar yang menyenangkan.

Undang-Undang Nomor 14 Tahun 2005 tentang Guru dan Dosen pada pasal 7 ayat $1 \mathrm{~b}$ menyatakan bahwa guru harus memiliki komitmen untuk meningkatkan mutu pendidikan, keimanan, ketakwaan dan akhlak mulia. Pasal tersebut menegaskan bahwa peran dan fungsi guru dalam meningkatkan mutu pendidikan hendaknya didasarkan pada komitmen guru, dan pemerintah mensyaratkan para guru untuk memiliki komitmen dalam melaksanakan tugas-tugas keguruannya.

Komitmen organisasi diartikan oleh Robbins dan Judge (2009:113) "the degree to which on employee identifies with a particular organization and its goals and wishes to mantaian membership in the organization" mendefinisikan komitmen sebagai keadaan dimana dimana seorang pegawai memihak pada suatu organisasi dan tujuan-tujuan serta keinginankeinginannya untuk mempertahankan keanggotaanya dalam organisasi.

Colquit, LePine, Wasson (2009:34) menjelaskan hal-hal yang mempengaruhi komitmen organisasi adalah cara kerja seseorang yaitu berupa variabel: kepuasan kerja, beban/tekanan kerja, motivasi kerja, kepercayaan dan kemampuan pengambilan keputusan. Selanjutnya dijelaskan variabel yang mempengaruhi cara kerja seseorang (individual mechanisms) adalah: (1) mekanisme pekerjaan seseorang yaitu budaya organisasi dan struktur organisasi; (2) mekanisme kelompok yaitu gaya dan perilaku pemimpin, kekuatan pemimpin dan pengaruhnya, tim kerja, karakter dari tim; (3) karakter indvidu yaitu berupa kepribadian dan nilai budaya seseorang; dan (4) kemampuan seseorang. Guru yang memiliki komitmen yang baik pada dirinya cenderung aktif dan bertanggung jawab dalam melaksanakan tugas, didalam sebuah organisasi sangat diperlukan komitmen pada setiap anggota, jika anggota organisasi telah memiliki komitmen pada dirinya, maka akan cenderung bekerja secara optimal sehingga dapat mencurahkan perhatian, pikiran, tenaga dan waktunya pekerjaanya. 
Berdasarkan hasil pengamatan peneliti yang pada tanggal 17 Januari 2019 di MAN 1 Pekanbaru, dan MAN 2 Pekanbaru ditemukan bahwa komitmen organisasi guru madrasah masih rendah hal ini dapat dilihat dari beberapa fenomena : (1) guru belum sepenuhnya memiliki tanggung jawab kerja yang maksimal, ditunjukkan dengan masih ada guru sering terlambat, tidak disiplin masuk dan pulang, meninggalkan kelas sebelum jam pelajaran berakhir, bahkan ada beberapa guru yang datang hanya untuk melakukan finger print, (2) guru belum sepenuhnya memberikan pelayan terbaik kepada peserta didik, ditunjukkan dengan masih ada guru yang belum menyiapkan/ mempersiapkan program pengajaran seperti membuat Silabus, RPP, Media pembelajaran, analisis butir soal, dan kisi-kisi soal, jarang melakukan program penilaian yaitu remedial, pengayaan dan memberikan umpan balik atau evaluasi kepada siswa dan jarang melakukan inovasi dalam pembelajaran, (3) kurangnya kepedulian guru terhadap organisasi ditunjukkan dengan masih ada guru yang tidak terlibat dalam kegiatan-kegiatan di sekolah seperti brifing, rapat dinas guru, upacara bendera dan kegiatan lain yang diadakan di madrasah. (4) guru belum menunjukkan teladan yang baik dalam mengikuti aturan-aturan organisasi sekolah seperti, tidak menggunakan baju dinas sesuai aturan sekolah. (5) lemahnya teamwork, ditunjukkan masih ada guru yang tidak mengikuti KKG (Kelompok Kerja Guru), dan MGMP (Musyawarah Guru Mata pelajaran) dan kegiatan pengembangan diri

Berbagai persoalan tersebut merupakan cerminan dari rendahnya komitmen kerja guru di sekolah yang dapat disebabkan oleh berbagai faktor. Maka untuk mencermati berbagai fenomena tersebut, perlu untuk menyelidiki lebih lanjut penyebab dan faktor-faktor yang mempengaruhi rendahnya komitmen kerja guru.

Diantaranya yang diduga mempengaruhi komitmen kerja guru adalah faktor budaya organisasi. Budaya organisasi yang kondusif dapat menggerakkan orang-orang dalam satu organisasi untuk melakukan aktivitas kerja. Adanya budaya organisasi yang baik, guru akan merasa bahwa sekolah adalah tempat bersosialisasi, tempat berdiskusi, dan tempat bekerja yang menyenangkan. Setiap budaya organisasi sekolah yang baik akan menciptakan suasana kerja yang lebih baik serta mendukung komitmen kerja dalam melaksanakan tugasnya.

Selain budaya organisasi faktor yang mempengaruhi komitmen kerja guru adalah kepuasan kerja dan gaya kepemimpinan. Kepuasan kerja merupakan faktor penting ketika individu bekerja. Kepuasan kerja yang dirasakan oleh guru akan sangat memengaruhi komitmen guru terhadap pekerjaannya. Organisasi yang mampu memberikan kepuasan kerja yang tinggi terhadap guru maka organinisasi tersebut akan mudah dalam membina guru.

Kepala sekolah adalah pemimpin pendidikan yang mempunyai peranan sangat besar dalam mengembangkan pendidikan. Berkembangnya semangat kerja, kerja sama yang harmonis, minat terhadap perkembangan kualitas pendidikan, suasana kerja yang menyenangkan serta perkembangan kualitas profesional guru banyak ditentukan oleh kepemimpinan kepala sekolah.

Gaya kepemimpinan adalah cara yang digunakan pemimpin dalam memengaruhi para pengikutnya (Mulyasa,2009:108). Dengan model dan gaya kepemimpinan tertentu seorang 
pemimpin mampu membangun komitmen guru. Cara berkomunikasi, mengawasi guru serta cara kepala sekolah mendelegasikan wewenang dapat berpengaruh terhadap komitmen kerja guru. Memperhatikan fenomena tersebut maka peneliti tertarik untuk menganalisis penelitian yang berjudul "Pengaruh Budaya Organisasi, Kepuasan Kerja dan Gaya Kepemimpinan Kepala Sekolah Terhadap Komitmen Kerja Guru MAN 1 Dan MAN 2 Pekanbaru". KAJIAN TEORI.

1. Komitmen Kerja

Menurut Mowday dalam Sopiah (2008:155) Komitmen kerja sebagai istilah lain dari komitmen organisasional. Komitmen organisasional merupakan dimensi perilaku penting yang dapat digunakan untuk menilai kecenderungan guru untuk bertahan sebagai anggota organisasi. Komitmen organisasional merupakan identifikasi dan keterlibatan seseorang yang relatif kuat terhadap organisasi. Komitmen organisasional adalah keinginan anggota organisasi untuk mempertahankan keanggotaannya dalam organisasi dan bersedia berusaha keras bagi pencapaian tujuan organisasi.

Menurut Mathis dan Jackson dalam Busro (2018:71) memberikan definisi komitmen organisasi merupakan tingkat kepercayaan dan penerimaan tenaga kerja terhadap tujuan organisasi dan mempunyai keinginan untuk tetap ada di dalam organisasi tersebut.

Komitmen organisasi adalah ikatan keterkaitan individu dengan organisasi, sehingga individu tersebut "merasa memiliki" organisasinya. Komitmen menunjukkan keyakinan dan dukungan yang kuat terhadap nilai dan sasaran yang ingin dicapai oleh organisasi. Komitmen organisasi yang tinggi dapat diperlukan dalam sebuah organisasi, karena terciptanya komitmen yang tinggi akan memengaruhi situasi kerja yang profesional. Komitmen organisasi bisa tumbuh disebabkan karena individu memiliki ikatan emosional terhadap organisasi yang meliputi dukungan moral dan menerima nilai yang ada serta tekad dari dalam diri individu untuk berbuat sesuatu agar dapat menunjang keberhasilan organisasi sesuai dengan tujuan dan lebih mengutamakan kepentingan organisasi dibandingkan dirinya sendiri.

Komitmen organisasi diartikan oleh Robbins dan Judge(2009:113) "the degree to which on employee identifies with a particular organization and its goals and wishes to mantaian membership in the organization"mendefinisikan komitmen sebagai keadaan dimana dimana seorang pegawai memihak pada suatu organisasi dan tujuan-tujuan serta keinginan-keinginannya untuk mempertahankan keanggotaanya dalam organisasi.

Menurut Luthans (2008:147) komitmen sebagai:Organizational commitment is most often defined as 1) a strong desire to remain a member of aprticular organization; 2) a williagness to exert high levels of effort on behalf of the organization; and 3) a define belief in, and acceptance of, the value and goals of the organization.Komitmen organisasi sering dimaknai sebagai : 1) hasrat yang kuat untuk tetap menjadi anggota suatu organisasi; 2) kesediaan untuk bekerja keras atas nama organisasi; dan 3) kepercayaan tertentu dan penerimaan individu terhadap nilai dan tujuan organisasi.

Dari beberapa definisi yang diuraikan di atas dapat sintesiskan bahwa komitmen kerja guru adalah kemauan yang kuat dari guru untuk 
tetap berada, bekerja, dan rasa memiliki organisasi.

2. Budaya Organisasi

Colqiut, Le Pine, dan Wesson (2009:547) menjelaskan bahwa budaya organisasi merupakan berbagai pengetahuan sosial dalam sebuah organisasi mengenai aturan, norma, dan nilai-nilai yang membentuk sikap dan perilaku karyawan.

Menurut Sutrisno (2011:2) budaya organisasi didefinisikan sebagai perangkat sistem nilai-nilai (values), keyakinan-keyakinan (beliefs), asumsiasumsi (assumptions) atau normanorma yang telah berlaku, disepakati dan diikuti oleh para anggota suatu organisasi sebagai pedoman perilaku dan pemecahan masalah-masalah organisasinya. Budaya organisasi merupakan suatu kekuatan sosial yang tidak tampak, yang dapat menggerakkan orang-orang dalam suatu organisasi untuk melakukan aktivitas kerja. Secara tidak sadar tiap-tiap orang didalam suatu organisasi mempelajari budaya yang berlaku di dalam organisasinya.

Menurut Luthans (2009:158159) organizational culture can defined as the shared values and beliefs that enable members to understand their roles and the norms of the organization. Budaya organisasi dapat didefinisikan sebagai nilai-nilai dan keyakinan bersama yang memungkinkan anggota untuk memahami peran mereka dan normanorma organisasi.

Wirawan (2007:10) menyatakan bahwa budaya organisasi sebagai norma, nilai-nilai, asumsi, kepercayaan, filsafat, kebiasaan organisasi dan sebagainya (isi budaya organisasi) yang dikembangkan dalam waktu yang lama oleh pendiri, pemimpin dan anggota organisasi yang disosialisasikan dan diajarkan kepada anggota baru serta diterapkan dalam aktifitas organisasi sehingga mempengaruhi pola pikir, sikap dan pola perilaku anggota organisasi dalam memproduksi produk, melayani para konsumen dan mencapai tujuan organisasi.

Budaya organisasi adalah suatu kebiasaan yang telah berlangsung lama dan dipakai serta diterapkan dalam kehidupan aktifitas kerja sebagai salah satu pendorong untuk meningkatkan kualitas kerja para karyawan dan manajer perusahaan (Fahmi, 2011:95).

Menurut Robbins (2002:284) budaya organisasi mendorong terciptanya komitmen organisasi dan meningkatkan konsistensi sikap karyawan. Adanya rasa kekeluargaan dan keterikatan yang tinggi, rasa saling menghargai dan keinginan untuk saling membantu diantara sesama guru dapat meningkatkan rasa nyaman dalam menjalankan tugas dan tanggung jawabnya sehingga dapat meningkatkan loyalitas dan kesetiaan terhadap institusi dan akan mengurangi keinginan untuk keluar dari institusi. Budaya organisasi yang kondusif sangat berpengaruh terhadap peningkatan komitmen organisasi.

Dari beberapa definisi yang dikemukakan oleh para ahli dapat disintesiskan bahwa budaya organisasi merupakan nilai,norma dan keyakinan yang dijadikan acuan dan dianut bersama oleh anggota organisasi untuk mencapai tujuan organisasi secara efektif dan efisien.

3. Kepuasan Kerja

Kepuasan kerja (job satisfaction) dapat didefinisikan sebagai suatu perasaanpositif tentang pekerjaan seseorang yangmerupakan hasil dari sebuah

evaluasikarakteristiknya.Seseorang dengan tingkatkepuasan kerja yang tinggi memiliki perasaanperasaanpositif tentang pekerjaan tersebut,sementara seseorang yang tidak 
puas memilikiperasaan-perasaan yang negatif tentangpekerjaan tersebut (Robbins \& Judge,2009:99).

$$
\text { Rivai \& Sagala (2009:856) }
$$

mengemukakan kepuasan kerja merupakan evaluasiyang menggambarkan seseorang atasperasaaan sikapnya senang atau tidak senang,puas atau tidak puas dalam bekerja.Kepuasankerja pada dasarnya merupakan sesuatu yangbersifat individu.Setiap individu memilikitingkat kepuasan kerja yang berbeda sesuaidengan sistem nilai yang berlaku pada dirinya.Semakin tinggi penilaian terhadap kegiatan dirasakan sesuai dengan keinginan individu, maka makin tinggi kepuasannya terhadap kegiatan tersebut.

Menurut Hasibuan (2012: 203) mengatakan kepuasan kerja dalam pekerjaan adalah kepuasan kerja yang dinikmati dalam pekerjaan dengan memperoleh pujian hasil kerja, penempatan, perlakuan, peralatan, dan suasana lingkungan kerja yang baik. Pegawai yang lebih suka menikmati kepuasan kerja dalam pekerjaan akan lebih mengutamakan pekerjaannya dari pada balas jasa walaupun balas jasa itu penting. Kepuasan kerja mempengaruhi tingkat kedisiplinan pegawai, artinya kepuasan diperoleh dari pekerjaan maka kedisiplinan pegawai baik. Sebaliknya jika kepuasan kerja kurang tercapai dari pekerjaannya maka kedisiplinan pegawai rendah, untuk itu pihak organisasi juga perlu memperhatikan kepuasan kerja pegawai.

Kepuasan kerja adalah perasaan menyenangkan atau tidak menyenangkanpada diri pegawai yang berhubungan dengan pekerjaannya maupun dengan kondisi dirinya. Perasaan yang berhubung dengan pekerjaan melibatkan aspek-aspek seperti upah atau gaji yang diterima, kesempatan pengembangan karir, hubungan dengan pegawai lainnya, penempatan kerja, jenis pekerjaan, struktur organisasi perusahaan, mutu pengawasan. Sedangkan perasaan yang berhubungan dengan dirinya, antara lain umur, kondisi kesehatan, kemampuan, pendidikan (Mangkunegara, 2007:117).

Kepuasan kerja adalah suatu sikap pegawai terhadap pekerjaannya yang berhubungan dengan situasi kerja, kerja sama antar pegawai, imbalan yang diterima dalam kerja, dan hal-hal yang menyangkut faktor fisik dan psikologis. Sikap terhadap pekerjaan ini merupakan hasil dari sejumlah sikap khusus individu faktor-faktor dalam pekerjaan, penyesuaian diri individu, dan hubungan sosial individu di luar pekerjaan sehingga menimbulkan sikap umum individu terhadap pekerjaan yang di hadapinya (Sutrisno, 2014:74).

Menurut Wirawan (2013:698) kepuasan kerja merupakan fenomena yang banyak dibahas oleh pakar psikologi, prilaku organisasi dan manajemen sumber daya manusia dan dihubungankan dengan kepemimpinan dan variabel lainnya.Kepuasan kerja adalah persepsi orang mengenai berbagai aspek dari pekerjaannya.pengertian persepsi berupa sikap positif atau negatif.

Kepuasan kerja adalah sikap emosional yang menyenangkan dan mencintai pekerjaannya.Sikap ini dicerminkan oleh moral kerja.Kedisiplinan, dan prestasi kerja.Kepuasan kerja dinikmati dalam pekerjaan, luar pekerjaan dan kombinasi dalam dan luar pekerjaan (Hasibuan, 2012:202).

Menurut Robbins dalam Busro (2018:101) mengatakan, kepuasan kerja merupakan perasaan positif tentang suatu pekerjaan yang merupakan hasil evaluasi dari beberapa karakteristik. Perasan positif maupun negatif yang dialami karyawan menyebabkan 
seseorang dapat mengalami kepuasan maupun ketidakpuasan kerja.

Dari beberapa definisi tersebut dapat disintesiskan bahwa Kepuasan kerja adalah ungkapan perasaan seseorang yang menyenangkan atau tidak menyenangkan yang berkaitan dengan pekerjaannya.

4. Gaya Kepemimpinan Kepala Sekolah

Gaya kepemimpinan menggambarkan dari falsafah yang konsisten, keterampilan, sifat dan sikap yang mendasari perilaku seseorang. Gaya kepemimpinan akan menunjukkan langsung tentang keyakinan seorang pemimpin terhadap kemampuan bawahannya. Artinya gaya kepemimpinan adalah, perilaku dan strategi, sebagai hasil kombinasi dari falsafah, keterampilan, sifat, sikap, yang sering diterapkan dari seorang pemimpin ketika ia mencoba mempengaruhi kinerja bawahannya (Rorimpandey, 2013).

Gaya kepemimpinan itu sendiri merupakan suatu pola perilaku yang ditampilkan sebagai pimpinan ketika mencoba memengaruhi perilaku orang lain. Oleh karena perilaku yang diperlihatkan oleh bawahan pada dasarnya adalah respon bawahan terhadap gaya kepemimpinan yang dilakukan pada mereka.

Gaya kepemimpinan lainnya didefinisikan sebagai teknik-teknik gaya kepemimpinan dalam memengaruhi bawahannya dalam melaksanakan tugasnya berdasarkan kewenangan dan kekuasaan untuk melaksanakan fungsifungsi manajemen (Suyanto, 2008).

Robbins dan Coulter, (2012) menyatakan gaya Pemimpin adalah seseorang yang dapat memengaruhi orang lain dan yang memiliki otoritas manajerial. Sedangkan kepemimpinan adalah apa yang para pemimpin lakukan, yaitu proses memimpin kelompok dan mempegaruhi kelompok untuk mencapai suatu tujuan.

Menurut Gibson dalam

Samsuddin (2018:37), gaya kepemimpinan merupakan cara yang dilakukan seorang pemimpin dalam memengaruhi perilaku maupun pikiran bawahannya sehingga mampu menjalankan tugasnya dalam upaya untuk mencapai tujuan organisasi.

Gaya Kepemimpinan adalah proses untuk memengaruhi orang lain untuk memahami dan setuju dengan apa yang perlu dilakukan dan bagaimana tugas itu dilakukan secara efektif, serta proses untuk memfasilitasi upaya individu dan kolektif untuk mencapai tujuan bersama (Yukl, 2010).

Menurut Thoha

(2013:49)

bahwa gaya Kepemimpinan merupakan norma perilaku yang digunakan oleh seseorang pada saat orang tersebut mencoba mempengaruhi perilaku orang lain seperti yang ia lihat.

Sedangkan Rivai (2014:42)

menyatakan gaya Kepemimpinan adalah sekumpulan ciri yang digunakan pimpinan untuk memengaruhi bawahan agar sasaran organisasi tercapai atau dapat pula dikatakan bahwa gaya kepemimpinan adalah pola perilaku dan strategi yang disukai dan sering diterapkan oleh seorang pemimpin. Gaya kepemimpinan yang menunjukkan, secara langsung maupun tidak langsung, tentang keyakinan seorang pimpinan terhadap kemampuan bawahannya. Artinya

gaya kepemimpinan adalah perilaku dan strategi, sebagai hasil kombinasi dari falsafah, keterampilan, sifat, sikap, yang sering diterapkan seorang pemimpin ketika ia mencoba memengaruhi kinerja bawahannya.

Thoha dalam Busro (2018:226) menyatakan, bahwa gaya kepemimpinan adalah suatu pola perilaku yang konsisten yang kita 
tunjukkan dan diketahui oleh pihak lain ketika kita berusaha memengaruhi kegiatan-kegiatan orang lain.

Suparyadi (2015: 454- 456) menyatakan adanya beberapa faktor yang memengaruhi terbentuknya komitmen organisasi, salah satunya, faktor internal. Faktor internal organisasi berupa ganjaran, pemimpin, rekan kerja dan kebijakan organisasi. Ganjaran yang diberikan oleh organisasi baik berupa gaji, promosi, pekerjaan yang menantang dapat memengaruhi tingkat komitmen invidu pada organisasinya. Gaya kepemimpinan dapat berpengaruh pada kesetiaan atau loyalitas anggota terhadap organisasi.

Berdasarkan pengertian dari para ahli di atas, maka disimpulkan bahwa gaya kepemimpinan adalah salah satu cara yang dipergunakan oleh seorang pemimpin dalam mempengaruhi, mengarahkan dan mengendalikan perilaku orang lain untuk mencapai suatu tujuan

\section{METODOLOGI PENELITIAN}

Metode penelitian dalam penelitian menggunakan metode survey dengan teknik korelasi. Pendekatan analisis yang dilakukan dalam peneltian ini adalah analisis jalur (path analisis). Subjek penelitian adalah 165 guru MAN 1 dan MAN 2 Pekanbaru. Jumlah sampel 117 Responden dengan teknik pengambilan sampel dengan cara proporsional random sampling dengan taraf signifikansi 0,05. Pengumpulan data dalam peenelitian ini menggunakan kuisioner dengan menggunakan skala likert.

\section{HASIL PENELITIAN DAN PEMBAHASAN}

Pembahasan hasil penelitian ini akan mengaitkan temuan-temuan peneltian dengan teori-teori yang relevan.

\section{Gaya Kepemimpinan Kepala Sekolah Terhadap Budaya Organisasi (Jalur} 1)

Berdasarkan hasil output pada tabel ANOVA diperoleh nilai $F$ sebesar 34.538 dengan nilai probabilitas $(\mathrm{sig})=$ 0,000 , karena nilai sig $<0.05$, maka keputusannya Ho ditolak dan $\mathrm{Ha}$ diterima artinya koefisien analisis jalur adalah terdapat signifikan. Artinya terdapat pengaruh antara gaya kepemimpinan kepala sekolah terhadap budaya organisasi.

Berdasarkan hasil analisis pada tabel Model Summary diperoleh nilai $\mathrm{R}$ Square sebesar 0,231 atau 23\%. Artinya dalam penelitian ini gaya kepemimpinan kepala sekolah mempengaruhi budaya organisasi sebesar $23 \%$ dan sisanya $77 \%$ dipengaruhi oleh faktor lain yang tidak menjadi bagian dari penelitian ini.

Besar koefisien residu $\epsilon_{1}=$ $\sqrt{1-0,231}=0,877$. Dengan demikian dapat digambarkan persamaan strukturalnya $\mathrm{X} 1=P_{x 3 \times 1}+\epsilon_{1}$

$\mathrm{X} 1=0,481 \mathrm{X} 1+0,877$.

Penelitian yang dilakukan oleh Agus Anas Fuadi (2014) dengan judul penelitian pengaruh kepemimpinan, budaya organisasi dan kepuasan kerja terhadap produktivitas kerja guru dengan komitmen organisasi sebagai moderating. Hasil peneltiannya menyimpulkan bahwa gaya kepemimpinan berpengaruh terhadap budaya organisasi.

\section{Gaya Kepemimpinan Kepala Sekolah Terhadap Kepuasan Kerja (Jalur 2)}

Berdasarkan hasil analisis Standardized Coefficients diperoleh nilai koefisien jalur pada $X_{3}$ terhadap $\mathrm{X}_{2}$ sebesar 0,471 , dan pada kolom sig (signifikansi) diperoleh nilai sig sebesar $0.000<0.05$, maka Ho ditolak dan $\mathrm{Ha}$ diterima artinya koefisien analisis jalur 
adalah signifikan. Artinya terdapat pengaruh langsung positif antara gaya kepemimpinan kepala sekolah terhadap kepuasan kerja guru. Berdasarkan hasil analisis diperoleh nilai koefisien determinan atau kontribusi $\mathrm{R}$ Square sebesar 0,215 dengan koefisien residu $\epsilon_{1}=\sqrt{1-0,215}=0,886$. Artinya dalam penelitian ini gaya kepemimpinan kepala sekolah mempengaruhi kepuasan kerja sebesar $88,6 \%$ dan sisanya $11,4 \%$ dipengaruhi oleh faktor lain yang tidak menjadi bagian dari penelitian ini.

Temuan penelitian ini diperkuat oleh penelitian yang dilakukan oleh Deasy Rachmawati Aziizah (2018) dengan judul penelitian pengaruh gaya kepemimpinan kepala sekolah dan budaya organisasi terhadap kinerja guru dengan kepuasan kerja, hasil penelitian menyimpulkan bahwa gaya kepemimpinan kepala sekolah berpengaruh langsung terhadap kepuasan kerja. Dengan adanya perhatian pimpinan terhadap gaji/upah dapat meningkatkan kepuasan kerja guru.

\section{Pengaruh Budaya Organisasi, Kepuasan Kerja dan Gaya Kepemimpinan Kepala Sekolah Terhadap Komitmen Kerja Guru (Jalur3).}

1. Pengujian secara individu jalur 3

a. Budaya Organisasi Terhadap Komitmen kerja Guru

Berdasarkan hasil analisis pada tabel Coefficients pada kolom sig (signifikansi) diperoleh nilai sig sebesar $0.027<0.05$, maka Ho ditolak dan $\mathrm{Ha}$ diterima artinya koefisien analisis jalur adalah signifikan. Artinya terdapat pengaruh antara budaya organisasi terhadap komitmen kerja guru.

Budaya organisasi berpengaruh terhadap komitmen kerja guru. Dari hasil perhitungan Standardized
Coefficients beta didapat pengaruh positif budaya organisasi terhadap komitmen kerja guru sebesar $0,054^{2}$ $=0,291$ atau 0,29\%. Artinya dalam penelitian ini budaya organisasi mempengaruhi komitmen kerja guru sebesar $0,29 \%$.

Menurut Robbins (2012:284) mengemukakan bahwa budaya organisasi mendorong terciptanya komitmen kerja dan meningkatkan konsistensi sikap karyawan. Adanya rasa kekeluargaan dan keterikatan yang tinggi, rasa saling menghargai dan keinginan untuk saling membantu diantara sesama guru dapat meningkatkan rasa nyaman dalam menjalankan tugas dan tanggung jawabnya sehingga meningkatkan loyalitas dan kesetiaan terhadap pekerjaan.

\section{b. Pengaruh Kepuasan Kerja Terhadap Komitmen Kerja Guru \\ Berdasarkan hasil analisis pada} tabel Coefficients pada kolom sig (signifikansi) diperoleh nilai sig sebesar $0.033<0.05$, maka Ho ditolak dan Ha diterima artinya koefisien analisis jalur adalah signifikan. Artinya terdapat pengaruh antara kepuasan kerja terhadap komitmen kerja guru.

Kepuasan kerja berpengaruh terhadap komitmen kerja guru. Dari perhitungan Standardized Coefficients beta sebesar $0,332^{2}=0,110$. atau $11, \%$. Artinya dalam penelitian ini budaya organisasi mempengaruhi komitmen kerja guru sebesar $11 \%$ dan sisanya $89 \%$ dipengaruhi oleh faktor lain yang tidak menjadi bagian dari penelitian ini.

Menurut Wibowo, (2013) mengemukakan bahwa karyawan yang mendapatkan tingkat kepuasan kerja yang lebih tinggi cendrung merasa tingkat affective commitment dan normative commitment tinggi. Senada 
dengan pendapat Parwita , (2013) dalam hasil penelitiannya, menjelaskan bahwa karyawan yang sudah terpenuhi kepuasan instrinsiknya akan menunjukkan kepedulian yang tinggi kepada perusahaan tempatnya bekerja. Hal ini menunjukkan bahwa tingkat kepuasan kerja tinggi maka tingkat komitmen terhadap organisasi akan tinggi pula.

\section{c. Pengaruh \\ Kepemimpinan \\ Gaya \\ Sekolah Terhadap Komitmen \\ Kerja Guru \\ Berdasarkan hasil analisis pada} tabel 4.16 Coefficients pada kolom sig (signifikansi) diperoleh nilai sig sebesar $0.007<0.05$, maka Ho ditolak dan $\mathrm{Ha}$ diterima artinya koefisien analisis jalur adalah signifikan. Artinya terdapat pengaruh antara gaya kepemimpinan kepala sekolah terhadap komitmen kerja guru.

Kepuasan kerja berpengaruh terhadap komitmen kerja guru. Dari perhitungan Standardized Coefficients beta sebesar 0,2512 =0,063 atau 6,3\% . Artinya dalam penelitian ini gaya kepemimpinan kepala sekolah mempengaruhi komitmen kerja guru sebesar 6,3\%.

Suparyadi (2015: 454- 456) menyatakan adanya beberapa faktor yang memengaruhi terbentuknya komitmen organisasi, salah satunya, faktor internal. Gaya kepemimpinan dapat berpengaruh pada kesetiaan atau loyalitas anggota terhadap organisasi. Dengan model dan gaya kepemimpinan tertentu seorang pemimpin mampu membangun komitmen kerja guru.

2. Pengujian secara bersama-sama atau simultan

Berdasarkan hasil output pada tabel ANOVA diperoleh nilai $\mathrm{F}$ sebesar 16.018 dengan nilai probabilitas (sig) $=$ 0,000 , karena nilai sig $<0.05$, maka keputusannya Ho ditolak dan $\mathrm{Ha}$ diterima artinya koefisien analisis jalur adalah terdapat signifikan. Artinya terdapat pengaruh antara budaya organisasi, kepuasan kerja dan gaya kepemimpinan kepala sekolah secara bersama-sama terhadap komitmen kerja guru.

Berdasarkan hasil analisis pada tabel 4.18 diperoleh nilai koefisien determinan atau kontribusi R Square sebesar 0,298 atau 29,8 \%. Artinya dalam penelitian ini gaya kepemimpinan kepala sekolah mempengaruhi kepuasan kerja sebesar $29,8 \%$ dan sisanya $70,2 \%$ dipengaruhi oleh faktor lain yang tidak menjadi bagian dari penelitian ini.

Besar koefisien residu $\epsilon_{3}=$ $\sqrt{1-0,298}=0,837$. Maka kerangka hubungan kausal empiris antara $\mathbf{X}_{\mathbf{1}}$ , $X_{2}$, dan $X_{3}$ terhadap $Y$ dapat dibuat persamaan strukturalnya sebagai berikut:

$\mathrm{Y}=\mathrm{P}_{\mathrm{Y} 1 \mathrm{X} 1}+\mathrm{P}_{\mathrm{Y} 2 \mathrm{X} 2}+\mathrm{P}_{\mathrm{Y} 3 \mathrm{X} 3}+\epsilon_{3}$ 


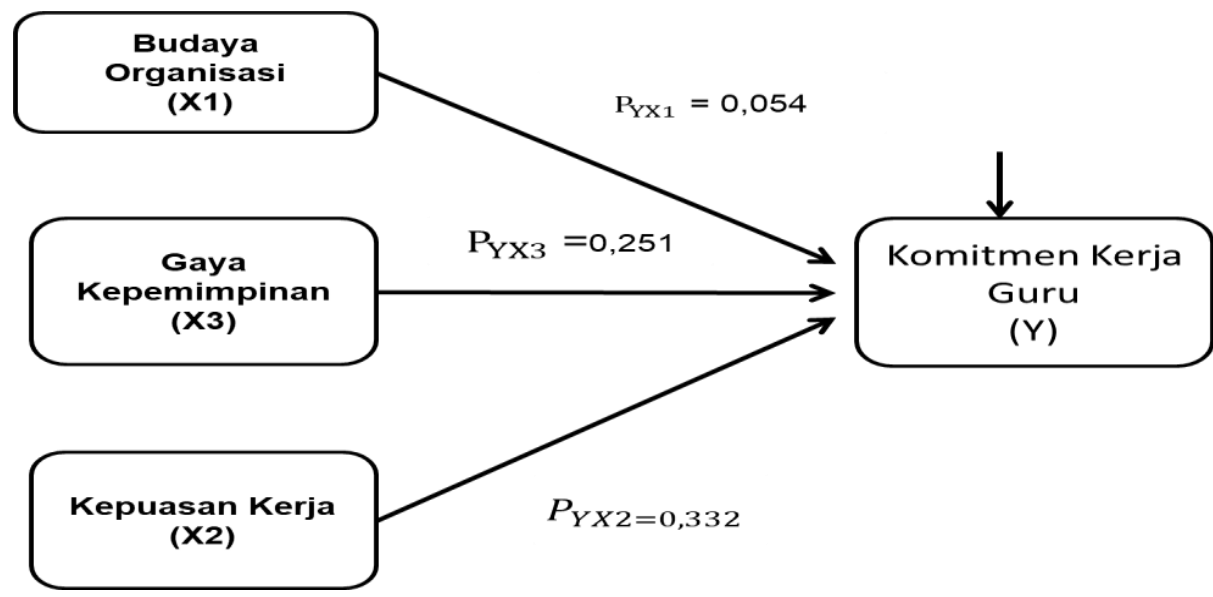

Gambar 1.

Diagram Jalur Variabel Penelitian Hasil Hengujian Hipotesis

\section{SIMPULAN}

Berdasarkan pengujian hipotesis dan pembahasan hasil penelitian, dapat disimpulkan hal-hal sebagai berikut:

1. Terdapat pengaruh langsung gaya kepemimpinan kepala sekolah (X3) terhadap budaya organisasi guru(X1) MAN 1 dan MAN 2 Pekanbaru.

2. Terdapat pengaruh langsung positif gaya kepemimpinan kepala sekolah (X3) terhadap kepuasan kerja guru (X1) MAN 1 dan MAN 2 Pekanbaru.

3. Terdapat pengaruh langsung budaya organisasi (X1) dengan komitmen kerja guru (Y) MAN 1 dan MAN 2 Pekanbaru.

4. Terdapat pengaruh langsung kepuasan kerja (X2) dengan komitmen kerja guru (Y) MAN 1 dan MAN 2 Pekanbaru. Kepuas an kerja guru dapat juga menentukan dan memberikan kontribusi terhadap komitmen kerja guru MAN 1 dan MAN 2 Pekanbaru.

5. Terdapat pengaruh langsung gaya kepemimpinan kepala sekolah (X3) dengan komitmen kerja guru (Y) MAN 1 dan MAN 2 Pekanbaru. Gaya kepemimpinan kepala sekolah dapat juga menentukan dan memberikan kontribusi terhadap komitmen kerja MAN 1 dan MAN 2 Pekanbaru .

\section{Implikasi}

Bertitik kesimpulan di atas, maka implikasi hasil penelitian ini akan diarahkan kepada upaya peningkatan komitmen kerja guru melalui variabel budaya organisasi, kepuasan kerja, gaya kepemimpinan kepala sekolah.

1. Aspek budaya organisasi merupakan salah satu unsur yang penting dalam upaya meningkatkan komitmen kerja guru karena budaya organisasi yang baik merupakan faktor penentu dalam meningkatkan komitmen kerja guru. Upaya-upaya yang dapat dilakukan oleh seorang guru dalam memperbaiki budaya organisasi adalah membangun kebersamaan dan kekompakan serta menambah frekuensi kegiatan bersama yang bermanfaat seperti kegiatan MGMP dan team work, dengan begitu jarak diantara sesama guru akan semakin dekat dan intens sehingga dapat membentuk komitmen kerja yang baik antara sesama guru. 
2. Dengan adanya pengaruh kepuasan kerja terhadap komitmen kerja guru, sebaiknya kepala sekolah dapat menciptakan suasana kerja yang dapat mendorong guru melaksanakan proses belajar mengajar baik berupa ruangan guru, alat mengajar infocus atau alat peraga dan juga dana insentif.

3. Aspek gaya kepemimpinan kepala sekolah merupakan salah satu unsur yang penting dalam upaya meningkatkan komitmen kerja guru. Tidak dapat dipungkiri bahwa gaya kepemimpinan kepala sekolah memiliki pengaruh yang kuat terhadap terbentuknya komitmen kerja guru oleh karena itu sebaiknya gaya kepemimpinan kepala sekolah dapat menuntun guru untuk bekerja lebih giat, jujur serta bertanggung jawab terhadap tugas yang diembannya sehingga pekerjaan dapat terlaksana dengan baik. Adanya perhatian dari pimpinan terhadap gaji, ruang guru dan sarana penunjang proses belajar akan menciptakan suasana kerja yang nyaman dan menyenangkan, yang pada akhirnya dapat meningkatkan derajat komitmen kerja guru.

\section{SARAN}

Berdasarkan hasil penelitian, simpulan dan implikasi penelitian yang dipaparkan sebelumnya, maka pada bagian ini perlu diberikan saran kepada pihak yang terkait dengan penelitian ini:

1. Pengaruh gaya kepemimpinan kepala sekolah terhadap budaya organisasi guru MAN 1 dan MAN 2 Pekanbaru berpengaruh langsung positif. Oleh sebab itu agar budaya organisasi terlaksana dengan baik sebaiknya kepala sekolah dapat melakukan evaluasi atau pengawasan terhadap tupoksi guru. Kepala sekolah hendaknya menciptakan kekompakkan antara sesama guru dan kepala sekolah, antara guru dan sesama guru, menciptakan rasa memiliki terhadap sekolah.

2. Pengaruh gaya kepemimpinan kepala sekolah terhadap kepuasan kerja guru MAN 1 dan MAN 2 Pekanbaru berpengaruh langsung positif. Kepuasan kerja guru akan meningkat apabila gaya kepemimpinan yang berorientasi pada tugas diperkuat. sebaiknya kepala sekolah dapat melakukan evaluasi atau pengawasan terhadap tupoksi guru serta lebih memperhatikan ruang tempat bekerja guru, karena dengan adanya ruang tempat bekerja yang nyaman dapat meningkatkan loyalitas terhadap pekerjaan akan meningkat juga.

3. Pengaruh budaya organisasi terhadap komitmen kerja guru MAN 1 dan MAN 2 Pekanbaru berpengaruh langsung positif. Oleh sebab itu diharapkan kepada guru MAN 1 dan MAN 2 Pekanbaru untuk lebih memperhatikan budaya organisasi disekolah, lebih inovatif dalam hal menciptakan proses pembelajaran, meningkatkan team work antar sesama guru sehingga dapat terjalin hubungan dan komunikasi yang harmonis serta loyalitas yang tinggi terhadap sesama guru dan pimpinanannya.

4. Pengaruh kepuasan kerja terhadap komitmen kerja guru MAN 1 dan MAN 2 Pekanbaru 
berpengaruh langsung positif. Oleh sebab itu diharapkan kepada kepala sekolah untuk dapat memberikan perhatian dalam hal pemberian reward untuk guru yang berprestasi dan memperhatikan tempat kerja guru, dengan adanya tempat bekerja yang nyaman akan meningkatkan loyalitas guru terhadap pekerjaannya.

5. Pengaruh gaya kepemimpinan kepala sekolah terhadap komitmen kerja guru MAN 1 dan MAN 2 Pekanbaru berpengaruh langsung positif. Oleh sebab itu diharapkan Kepala untuk dapat memberikan perhatian, motivasi dan pembinaan terhadap guru dalam hal tupoksi guru serta melakukan evaluasi terhadap tugas guru sehingga dapat meningkatkan komitmen kerja guru.

\section{DAFTAR PUSTAKA}

Abdulah, Ma'ruf. (2015). Metodologi Penelitian Kuantitatif. Yogyakarta: Aswaja Persindo.

Agustin Eka Nurhayati. (2015). Pengaruh Kepuasan Kerja, Motivasi, dan Persepsi Atas Dukungan Organisasional Terhadap Komitmen Organisasi Guru Taman Kanak-Kanak Di Kecamatan sanden, Kabupaten Bantul, Yogyakarta. Jurnal Manajemen, Fakultas Ekonomi Universitas Sarjanawijayata Tamansiswa.

Colquit,Lepine, Wesson, (2009). Organizational Behavior,Improving
Performance and Commitmen in the Workplace. Newyork: Mc.Graw Hill Irwin.

Fahmi, Irfan, (2014). Perilaku Organisasi Teori, Aplikasi, dan Kasus. Bandung. Alfabeta.

Hasibuan, S.P, Malayu, (2012), Manajemen Sumber Daya Manusia Edisi revisi. Jakarta : Bumi Aksara.

Herjany Ericca, (2018). Pengaruh lingkungan kerja, kepuasan kerja, dan stres kerja terhadap komitmen organisasi Guru TK dan SD pada Sekolah X Di Jakarta. Jurnal Manajemen Indonesia Universitas Pelita harapan, Tangerang.

Kartono, Kartini, (2008). Pemimpin dan kepemimpinan. PT RajaGrafindo Persada.

Luthan, fred. (2008). Organizational Behavior.11 ${ }^{\text {th }} \quad$ Edition. Singapore, McGraw-Hill/irwin.

Luthan,Doh, (2009), International management. Singapore, McGraw-Hill/irwin.

Mahmud, (2011), Metode Penelitian Pendidikan, Bandung, CV Pustaka Setia.

Maizar Saputra, Wahyu Raharjo. (2017). Pengaruh Iklim Organisasi, Kepuasan kerja, keterlibatan Kerja Terhadap Komitmen Organisasi Pada Karyawan PT X. Jurnal Psikologi. Fakultas Psikologi Universitas Gunadarma. 
Mangkunegara, Anwar Prabu (2009). Manajemen Sumber Daya Manusia Perusahaan. Bandung :PT Remaja Rosdakarya.

Maya Yusnita, (2016). Pengaruh Masa Kerja dan Kepuasan Kerja terhadap Komitmen Organisasi Guru Honor (Studi Kasus pada SMA Unggulan di Kota Palembang). Journal of Business and Economics (IJBE) Vol 1.

McShane,Steven L,dan Mary Ann Vonn Glinow. Organizational Behavior $4^{\text {th }}$.Edition. New York Mvgraw_Hill Companies, Inc.

Muhammad Busro, (2018), Teori-teori Manajemen Sumber Daya Manusia. Edisi pertama. Jakarta:Prenada Media.

Muhid, Abdul dan Susiawan, Susilo (2015), Kepemimpnan Transformasional, Kepuasan Kerja dan Komitmen Organisasi. Jurnal Psikologi Indonesia. Fakultas Psikologi Universitas 17 Agustus 1945 Surabaya.

Mulyasa, E (2012), Manajemen dan kepemimpinan Kepala Sekolah, Jakarta : PT Bumi Aksara.

Newstrom,Jhon W, dan Keith Davis. (2011). Organzational behavior,Human Behavior at Work. New York:McGrawHill/Irwin.

Ni Made Dwi Puspitawati dan Gede Riana. (2016). Pengaruh Kepuasan Kerja Terhadap Komitmen Organisasional dan
Kualitas Layanan. Jurnal Manajemen, Strategi Bisnis dan Kewirausahaan,
Nurmansyah, (2016). Perilaku Organisasi. Edisi Revisi \&pengembangan. Pekanbaru: Unilak Press.

Pahmi, Idrus Taba, Mahlia Muis, (2015). Pengaruh Gaya Kepemimpinan dan Kepuasan Kerja Terhadap Kinerja Pegawai Melalui Komitmen Organisasi. Jurnal Manajemen dan Keuangan, Fakultas Ekonomi dan Bisnis Pasca Sarjana Unhas.

Rahmayani,dkk (2017), Pengaruh Iklim Organisasi, Motivasi Kerja dan Kepuasan Kerja Terhadap Komitmen Organisasi Guru SMP Negeri Di kecamatan Silih Nara kabupaten Aceh Tengah, Jurnal Manajemen Pendidikan, ISSN :1979-6684, Lembaga Universitas Negeri Medan.

Riduwan, (2015). Metode \& Teknik Menyusun Proposal Penelitian. Bandung: Alfabeta.

Riduwan, (2015). Metode dan Teknik Menyusun Tesis. Bandung : Alfabeta.Riduwan, 2013. Cara Menggunakan Dan memakai Path Analysis (Analisis Jalur; Bandung. Alfabeta.

Robbins, Stephen L. (2012). Perilaku Organisasi. Jakarta : Salemba Empat.

Robbin, Stephen P, dan Thimoty Judge. (2009). Organizational Behavior, $13^{\text {th }}$ Edition. Upper 
Saddle River, New Jersey: Perason Education, Inc.

Sagala, Syaiful. (2007). Manajemen Strategik dalam Peningkatan Mutu Pendidikan. Bandung : Alfabeta.Sopiah, 2008. Perilaku Organisasi. Yogyakarta : CV Andi Offset.

Sugiyono. (2014). Metode Penelitian Pendidikan Pendekatan Kuantitatif, Kualitatif, dan $R \& D$. Bandung : Alfabeta.Sugiyono, 2010. Statistik untuk Penelitian. Bandung : Alfabeta.

Sugiyono. (2015). Metode Penelitian Pendidikan.

Bandung, Alfabeta.

Suherman, (2018), Pengaruh kepemimpinan dan motivasi kerja terhadap komitmen organisasional pegawai pusat pendidikan kelautan dan perikanan.

Sujarweni,V.Wiratna. (2014). SPPS untuk penelitian.Yogyakarta :Pustaka Baru Press.

Sukmadinata,Nana Syaodih, (2015). Metode Penelitian Pendidikan. PT Remaja Rosdkarya. Bandung.

Sumanto dan Anik Herminingsih, (2016), Pengaruh Budaya Organisasi dan Motivasi Kerja Terhadap Komitmen Organisasional Pada PT. Bank Central Asia, TBK. Kantor Cabang Utama Tanggerang, dalam Jurnal Ilmiah Manajemen dan Bisnis, Volume 2, Nomor 1, Maret
2016, Lembaga Universitas Mercu Buana Jakarta.

Sunyoto, Danang, (2012). Manajemen Sumber Daya Manusia. Yogyakarta : CAPS.

Suparyadi, (2015). Manajemen Sumber Daya Manusia, Jakarta, Tiga Serangkai.

Sutrisno, Edy, (2010). Budaya Organisasi. Jakarta: Kencana Group.

Tiur Asi Siburian, (2013) Faktor Penentu Komitmen Organisasi Guru SMA. Jurnal Ilmu Pendidikan Universitas Negeri Malang.

Tobing, dkk, (2017). Pengaruh Budaya Organisasi, Gaya Kepemimpinan Kepala Sekolah, dan Motivasi Kerja Terhadap Komitmen Kerja Guru Di Sekolah Menengah Atas negeri Kota tebing Tinggi. Dalam Jurnal Manajemen $\begin{array}{lll}\text { pendidikan } & \text { Vol.9 No.2 }\end{array}$ November 2017, Lembaga Universitas Negeri medan.

Wadiah, Lasmi, Mia. (2016). Teori Perilaku dan Budaya Organisasi. Bandung : Pustaka Setia.

Wahjosumidjo, (2011), Kepemimpinan Kepala Sekolah, Jakarta, PT Raja Graha Persindo Persada.

Wibowo, (2011). Manajemen Kinerja. RajaGrafindo Persada.

Wirawan. (2007). Budaya dan Iklim Organisasi. Salemba empat. Jakarta. 
Yulan. Innocentius Bernarto, (2017).

Pengaruh Self Efficacy,

Budaya Organisasi dan

Motivasi Kerja Terhadap

Komitmen Organisasi. Jurnal

Manajemen, Universitas Pelita

harapan, Tangerang.

Zainal, Rivai, Veithzal, dkk, (2014).

Kepemimpinan dan Perilaku

Organisasi Edisi keempat.

Jakarta: PT RajaGrafindo

Persada. 